Island Studies Journal, Vol. 7, No. 2, 2012, pp. 215-234

\title{
Virtually Impossible: Deleuze and Derrida on the Political Problem of Islands (and Island Studies)
}

Stewart Williams

School of Geography and Environmental Studies

University of Tasmania, Australia

Stewart.Williams@utas.edu.au

\begin{abstract}
It is commonplace to think of an island as a discreetly bounded unit. Selected writings on islands by the poststructuralist philosophers Gilles Deleuze and Jacques Derrida reveal the island variously to be both real and imaginary, mythological and scientific, but as most problematic when constituted in political terms as an indivisible, sovereign entity. These two thinkers' more broadly developed concepts of the virtual and the impossible, respectively, are seen to disrupt any assumptions about the fixity and closure of the island polity. Instead they emphasize its actualization through processual relations that can be difficult yet dynamic and decisive in effecting the move from being to becoming-other. As the possibilities for instituting more ethical as well as different political relations open up, the question of island studies remaining in its currently coherent, familiar form is raised for consideration.
\end{abstract}

Keywords: Deleuze; Derrida; impossible; island studies; poststructuralist politics; virtual

(C) 2012 Institute of Island Studies, University of Prince Edward Island, Canada

\section{Introduction}

The island's presumed unity follows its physical geography as a body of land in contradistinction to surrounding waters. Thus there is a common conception (or rather misconception) with the pictorial representation of islands erring towards a perfect, totalizing circumscription of space:

Ask anyone to take a sheet of paper and to draw an island as seen from the air. Most likely, that person would draw a stylized image of a piece of land, without much detail other than being surrounded by water. It would fit within the space confines of the sheet. It would also, uncannily, have an approximately circular shape. (Baldacchino, 2005: 247)

Of course, we know that the reality is far more complicated. Islands can be marshy, tidal, peninsular or bridged; yet others are caught somewhere between being rocky outcrops or islets and serving alternatively as mainlands (for other islands) as well as continents; and questions arising around matters of size and remoteness extend then to definitions of isolation, insularity and islandness (Baldacchino, 2007; Bradshaw \& Williams, 1999; Royle, 2001; Steinberg, 2005; Steinberg, 2009; Williams, 2010). This journal is itself replete with cases demonstrating the complexity of islands as they range between closure and openness, interiority and exteriority, singular fixity and diasporic multiplicity. But, as these cases also reveal, islands (and not least those qualities contributing to what gets described as islandness) exist inside the 


\section{S. Williams}

tight mental frameworks of our mind as much as in the messy reality of our concrete worlds (Baldacchino, 2006; Hay, 2006). They are also constituted in relational terms through a political as well as geographical imaginary.

Discussing islands as "objects of representation", Baldacchino notes how a person at arrival either on or near an island "...experiences early on a craving to circumnavigate, circumambulate or climb its highest point and take it all in" (2005: 247). Herein lies a point well worth drawing out. It is only through being viewed, surveyed, or mapped (directly through embodied practice or in the mind's eye) that such a place ever gets to be defined and categorized as a particular type of object, as an island, and objectified as such; and likewise, it is only with some realization and hence planning and preparation as well as management of the time spent there that people recognize themselves as subject to or subjects of an island, and thus as islanders as such. This intimate relationship between people and place is constitutive of its terms, situating objects and subjects in time and space as the island and its islanders are cleaved together (and subsequently connected to others elsewhere). It is intensely political, too.

Thinking of an island in political terms, constituted as an island polity, is offered here as a means to elucidate its contradictory nature. Questions of identity and sovereignty, which have been little explored in relation to the ontological and epistemological status of islands, are especially pressing here. Poststructuralist philosophers, Gilles Deleuze and Jacques Derrida, in addressing the politics of being and becoming, have made insightful contributions referring specifically to islands. Such references can appear to have been made mostly in passing. However, the central concerns of Deleuze and Derrida, such as the assumptions made about the unified meaning of any one text or the solid empirical basis for a nation-state's coherence are reflected in many ways in the problematic of the island polity. These authors' writings on islands have not as yet been collated or reviewed in any comprehensive manner, and so are brought here together for introduction to island studies scholars. Although they were written in a context and for purposes not directly concerning islands, their value in providing a much needed theoretical perspective on islands and island studies will be demonstrated. These writings are linked to the broader work of Deleuze and Derrida before then being examined in turn and with respect to island studies scholarship.

Deleuze and Derrida have each produced a body of work that is explicitly political in its own unique way; and yet whilst quite different, there are significant synergies (Beardsworth, 1996; Patton, 2000; Patton \& Protevi, 2003). As poststructuralists they both challenge the claims inherent in any objective or positivist structure but one major line of fracture and variation between them contrasts their respective lines of thought as immanent versus transcendent (Smith, 2003). The distinction holds in as much as Derrida works inside (and away at) the representational frame of epistemology whilst Deleuze engages with the productive material of ontology. Still, the difference between them can be striking: "It is the difference between No and Yes" (Bearn, 2000: 441). Their thinking can sometimes be at cross-purposes, but drawing on Deleuze and Derrida together is not wholly unthinkable. It also suits the doubly difficult nature of the subject matter at hand here. Indeed, these two thinkers can be harnessed alongside each other very successfully because, as will be demonstrated, their respective notions of the virtual and the impossible are conceptualizations central to their oeuvres; together, they provide excellent tools for prising open our very particular problematic of the island polity. 


\section{Deleuze: The Virtual Opening of Island Territory}

Gilles Deleuze produced - often with co-author Félix Guattari - some of the twentieth century's most spatially nuanced philosophy. With the concepts of smooth and striated space, the nomadic and sedentary, and de- and re-territorialization, Deleuze sees everything as emergent, taking place on a plane of immanence through processes of connection and becoming which he organizes conceptually in terms of layers described as geological strata and multiple plateaus (Deleuze \& Guattari, 1987; also Bonta \& Protevi, 2004; Buchanan \& Lambert, 2005; Doel, 2000). Much of Deleuze's work focuses on the problems of the state as a territorial machine and repressive apparatus that encodes power amidst the global flows of capitalism. He therefore analyses such matters in relation to a universal history through which the world's concrete social formations have repeatedly, yet every time differently, unfolded across the earth's surface.

Deleuze and Guattari's working together culminates in questions they ask of "geo-philosophy" in their final book What is Philosophy? (1994). Their interrogation of the earth and its peoples follows particular moments and milieus including the Ancient Greek city and the modern nation-state as providing opportunities for our becoming truly democratic. It is conducted by them apparently with "good reason" not least because "...the problem of the State-Form of Sovereignty has been one of the most difficult questions to resolve historically" (Lambert, 2005: 223). This state entity has a parallel or overlain form in the island polity. Deleuze's references to islands are thus hinted at here as the spaces of the city-state are shown as dynamic: "The man of capitalism is not Robinson but Ulysses, the cunning plebeian, some average man or other living in the big towns, Autochthonous Proletarians or foreign Migrants who throw themselves into infinite movement - revolution" (Deleuze \& Guattari, 1994: 98).

In their own Nietzschean manner, Deleuze and Guattari have together created new concepts in an explicitly political and "untimely" act of calling forth "... a new earth, a new people" (1994: 99 emphasis in original). These concepts exist as pure events or singularities indeterminately related to others, but they are also, as incorporeal transformations expressed in language, attributed to bodies and states of affairs. So, beyond just representing the world, they intervene in it. As explained more deeply in Difference and Repetition (1994), Deleuze sees such repetitions as therefore producing difference rather than simply reproducing sameness. His interest is with difference in itself contra those representations or simulacra based on the Platonic model of identification with the One or Same.

Alternatively, Deleuze draws on the concept of a virtual multiplicity which he first developed in Bergsonism (1988). Here, he shifts focus from the extensive to intensive nature of things, from their spatial distribution to temporal duration. His interest moves away from numbers and space, which are infinitely divisible and yet will still always produce only more of the same, towards what are qualitative, non-numeric multiplicities that change in kind with their division. Deleuze discusses light, sound and temperature as examples. Such intensive differences result from the dynamic, self-organization of material and energy that comprises the virtual "in such a way that it is actualized by being differenciated and is forced to differenciate itself, to create its lines of differenciation in order to be actualised" (Deleuze, 1988: 97). Importantly, this field 


\section{S. Williams}

of virtuality and its actualization far exceed any simple realization of the possible (with the latter being quite different since necessarily limited to a set of predefined forms).

\section{Deserted Islands}

Deleuze's concepts are never simply to be applied (for example, to islands as things to be studied). Instead, they provide us with a way into thinking about our world's emergence on a plane of immanence. Islands in the Deleuzean corpus are seen not so much as empirical phenomena for examination as ideas opening into thought. The key text dedicated to this subject matter - an early essay first published in the 1950s "Causes et raisons des iles désertes" now in translation as "Desert islands" (Deleuze, 2004) - therefore concerns islands as imaginary and mythological as well as real but above all as creative irruptions. The essay starts with a simple observation:

Geographers say there are two kinds of islands. This is valuable information for the imagination because it confirms what the imagination already knew. Nor is it the only case where science makes mythology more concrete, and mythology makes science more vivid. Continental islands are accidental, derived islands. ... Oceanic islands are originary, essential islands. ... These two kinds of islands, continental and originary, reveal a profound opposition between ocean and land. (Deleuze, 2004: 9 emphasis in original)

An elemental conflict arises with Deleuze's observations on the island as he comments on it emerging from between sea and earth, gendered as mother or father, isolated or connected, populous or deserted. Rather than opt for any one state over another, however, he explores the relations of force and intensity that are encountered simultaneously in terms of a geological earth science and human, cosmographic spirituality. Deleuze affords a key role to the Platonic Idea as much as the thing-in-itself. Thus he sees "the double movement that produces islands in themselves" in terms of psychogenesis, creating an island as "...the origin, radical and absolute" (Deleuze, 2004: 10 emphasis in original).

Although physical geography and creative imagination are collapsed together in Deleuzean thought, the latter prevails. It is the idea of an island that is most forceful. Through processes of separation and recreation, an island is produced materially as people approach it from outside and reproduce its originary or derived creation. The subject/object distinction is eroded in this imagining of an island. Or, as one reading of the essay suggests: "The island, like whoever desires it, is of a conscience unto itself ... being at the same time of the perceiver and the perceived alike" (Conley, 2005: 212). Deleuze's island as a deserted isle likewise remains deserted even when inhabited. It can contain a desert as might a continent, but there is also a desert outside of the island in the form of the surrounding sea that envelops it as an egg. In this sense, the desert island is at the very centre of life and fecundity.

Still, the dominant theme of the island for Deleuze (2004: 13) "is not production of life ... but its reproduction" and thus as a "second origin ... more essential than the first, since it gives us the law of repetition, the law of the series, whose first origin only gave us moments." It is the myth of the world beginning anew: 
Here we see original creation caught in a re-creation, which is concentrated in a holy land in the middle of the ocean. This second origin of the world is more important than the first: it is a sacred island. Many myths recount that what we find there is an egg, a cosmic egg. Since the island is a second origin, it is entrusted to man and not the gods (Deleuze, 2004: 13).

But these myths, according to Deleuze, have died and since been replaced by the bourgeois, secular values evinced in such classic literature as Giraudoux's Suzanne and the Pacific (1975 [1921]) and Defoe's Robinson Crusoe (1900 [1719]). Therefore, the protagonists in both tales are deprived of partners in any meaningful sort of relationship, and each instead engages with "cadavers" or "a slave", respectively, in their reproduction of what Deleuze considers was becoming or had become (there in Europe as well as the island) a familiar but banal, bourgeois political economy.

As a repetition of the same, neither the island depicted in such tales, nor in its potential for novelty and difference, is fully realized there or elsewhere. In its virtual multiplicity, however, the island is no longer a fixed point in time and space, nor is it simply a historical, literary or cartographic representation. Instead, it is emergent as an intensely powerful singularity, both material and conceptual, caught on a wave of becoming as it continually gets assembled and then re-assembled ever differently in becoming-other. The island constantly changes, unfolding and refolding on a line of flight in all directions across the surface of the globe.

\section{Other Islands}

Islands are often taken to embody absolute security, fixity and closure, identified with the sameness of an assumed interiority and insularity, but for Deleuze they exemplify becomingother since constituted through the outside and open to difference. Therefore, they are discussed at length by him in a later essay, and again with reference to Defoe's Robinson Crusoe or rather another fictional iteration of that tale about a deserted island. Through the chapter-long meditation 'Michel Tournier and the world without others' in his book The Logic of Sense, Deleuze (1990: 331-321) engages with Tournier's re-telling of the Robinsonade as the story of Friday on the island of Speranza. It is a fascinating story used by Deleuze to explore how otherness functions (or not) to structure the world:

With Tournier, Deleuze seeks the effects of the presence of other people in our everyday world, in order to conclude what Otherness is, and also what it would be like to live without other people. (Boundas, 1994: 110)

As Tournier's narrative unfolds, Robinson is not returned to civilization but is instead progressively dehumanized. Robinson hovers between states of neurosis and psychosis, succumbing to the earth as he curls up his body in the lush greenery and submerges himself in the muddy wallow, or alternatively rises upward through the airy skies to merge with the sun and light. Ultimately though, he loses his own sense of identity as he and the island and all its denizens are rendered up irreversibly to the elements in a movement that eventually sees them consumed in a massive conflagration. 


\section{S. Williams}

The isle is as much the hero of the novel as Robinson or Friday. It changes shape in the course of a series of divisions, no less than Robinson himself changes his form in the course of a series of metamorphoses. Robinson's subjective series is inseparable from the series of states of the island. (Deleuze, 1990: 302)

Deleuze notes how in Defoe's tale Robinson returns to the ship to gather materials for replicating a strict order of work whereas with Tournier there is no such reproduction. Rather than seek an equivalent economic reality based on a return to the origin, and hence an existence without sexuality, Tournier's Robinson lives in a purely material and libidinal desert island economy where he will ultimately become one with the island and engulfed by its great sexual as well as cosmic energy. In this tale of ends rather than origins, suggests Deleuze, is an implicit deviation and perversity. Robinson's relationship with Friday was always going to be ambiguous (having initially tried on meeting to shoot him but missing). Now tied together in the struggle for material survival, they still must deviate in relation to any prescribed ends. In fact, describing Friday as "identified with Venus" and "myself feminine and the bride of the sky", Robinson states: "The truth is that at the height to which Friday and I have soared, difference of sex is left behind" (Tournier, cited in Deleuze, 1990: 304). Their individual identities have collapsed together in this event of pure intensity. Robinson and Friday are no longer distinct in the process of their mutual dissolution. Indeed, the de-subjectivization resulting here is what embodies the perversity that is the island of Speranza. According to Tournier, such de-subjectivization defines perversion specifically as the failure to apprehend others as Other.

However, Tournier's story is more than a thesis on perversion as it deeply explores this absence of others. Notably, Deleuze explains that by 'others' is meant here not just subjects or objects but rather their necessary structuring relative to each other in any number of perceptual fields and hence their possible actualization of a world. As Robinson realizes, a world without others is one without possibilities, neither past nor future, and starkly limited by necessity:

What happens when Others are missing from the structure of the world? In that case, there reigns alone the brutal opposition of the sun and the earth, of an unbearable light and an obscure abyss: the "summary law of all or nothing." The known and the unknown, the perceived and the unperceived confront one another absolutely in a battle with nuances. "My vision of the island is reduced to that of my own eyes, and what I do not see of it is to me a total unknown. Everywhere I am not total darkness reigns." A harsh and black world, without potentialities or virtualities: the category of the possible has collapsed. Instead of relatively harmonious forms surging forth from, and going back to, a background in accordance with an order of space and time, only abstract lines now exist, luminous and harmful - only a groundless abyss, rebellious and devouring. Nothing but Elements (Deleuze, 1990: 306).

In a world without others one is unable to distinguish self from other or to recognize subjects and objects as such relative to each other in time and space. They are wholly Other, absolute and singular, arising as elemental doubles and surface images at the horizon between earth and sky, arrived at through some deviation - a detour obtained through catastrophe. 
The world's virtuality is not mere abstraction. Rather, it exists in all the possibilities of the world irrespective of whether they already are or might ever be realized (or not) and so is always there as part of what can then get actualized. It can exist in reality and potentially as an island which gets imagined and enacted as a state, territory, polity or economy, for example. However, "it does not exist (actually) outside of that which expresses it" or, as Deleuze (1990: 307) further explains:

It implicates it, it envelops it as something else, in a kind of torsion which situates what is expressed in the expressing. When I, in turn and for my part, grasp the reality of what the Other was expressing, I do nothing but explicate the Other, as I develop and realize the corresponding possible world. It is true that the Other already bestows a certain reality on the possibilities which he encompasses - especially by speaking. The other is the existence of the encompassed possible. Language is the reality of the possible as such. The self is the development and the explication of what is possible, the process of its realization in the actual.

For Deleuze, this relationship of otherness is critical to the constitution of any identity, including subjects and objects, self and other, thereby contributing to the possible worlds they create. In this case, various islands and island phenomena come into being through forces experienced either from inside or out. The island identities most lastingly captured by Defoe in the personae of Robinson and Friday therefore cannot help but be transformed through the intense relationship that follows their meeting and as reworked by others such as Tournier. These (otherwise insular) entities are caught between land and sea, impelled in an interminable line of flight to the horizon, open to all elements and possibilities.

Deleuze was enamoured by the Nietzschean roll of the dice whereas Derrida is deemed more of a pessimist (Bearn, 2000). Therefore, in the guise of an island studies scholar, Deleuze might quite happily cast himself adrift so as to be able then to explore unhindered, in life-affirming manner, any prospects for re-territorialization. On the other hand, Derrida (1995: 27-28) mentions islands as places of retirement, return and a retreat into the past: "If I had to retire to an island, it would be particularly history books, memoirs, that I would doubtless take with me, and that I would read in my own way, perhaps to make literature out of them, unless it would be the other way round, and this would be true for other books (art, philosophy, religion, human or natural sciences, law, etc.)." However, any such round of negation or closure offered by Derrida, especially if taken as implying impossibility, deserves a closer reading.

\section{Derrida: The Impossible Closure of Island Sovereignty}

The island polity's problematization is amenable to a Derridean interpretation given that Derrida's project was a radical interrogation of the philosophical underpinnings of Western culture. Recurrent themes concern matters of writing, representation, law and justice but the later work exhibits an increasingly overt politicization with an emphasis on questions of statehood, sovereignty and democracy. Likewise, his longstanding project of deconstruction based on the notions of differance, supplement, trace and pharmakon is attended by the ongoing development of his ideas of impossibility and undecidability grounded in the aporos 


\section{S. Williams}

or aporia. Deconstruction implies the deferral of meaning as well as its proliferation, and hints at Derrida's temporal or historical as well as geographical leaning. The spatial is still relevant (including in terms of textual positions and margins), but best understood in terms of his thinking on space and spacing described as "the becoming-space of time or the becoming-time of space" (Derrida, 1982: 13).

Unlike Deleuze's tendency to follow a hundred lines of flight in all their vitality, Derrida focuses on the one iteration as it gets framed in terms of absence and death as well as the endless deferral of any one full and final meaning. His space and spacing run up against limits, borders and boundaries, certainly, as he has a passion for the impossible, but there is also that which never arrives (such as the perfectly idealized, transcendent objectives of justice or democracy). In Aporias (1993) Derrida compares the aporos to a border, threshold, doorway or passage that is impossibly difficult, seemingly impracticable and yet never totally closed. It is, he says, "the impossible passage, the refused, denied, or prohibited passage, indeed the nonpassage, which can in fact be something else, the event of a coming or of a future advent which no longer has the form of the movement that consists in passing, traversing, or transiting" (Derrida, 1993: 8).

The impasse as impossibility not only represents constraint because it is also what precedes the possibility of a judgment or decision. The impossible thereby offers passage or an opportunity to advance (even if ending reason and choice because, as a de-cision, it "cuts off" and moves away from any further thought or alternative course of action on the matter). It reaches beyond universal forms of standard reasoning too, as the impossible demands more than just a calculation where the results can be known in advance. The impossible, as aporetic, demands an ethical response from us in selecting only one out of several equally justifiable solutions:

[I]f you don't experience some undecidability, then the decision would simply be the application of a program, the consequences of a premiss or of a matrix. So a decision has to go through some impossibility in order for it to be a decision ... Ethics and politics therefore start with undecidability (Derrida, 1999: 66).

Derrida therefore progresses his broader ethico-political inquiry with references made on several occasions to the aporetic figure of the island.

\section{Islands Unbound}

Derrida has described the contentious spaces of law courts, temples and sanctuaries as well as borders and thresholds as aporetic places marking the sacred from the profane, for example, in "Force of law" (1990), "Beyond the law" (1992a) and "Faith and knowledge" (2002a). It is in the latter long essay, first delivered as Foi et savoir, and now known in its more developed form and translation as "Faith and knowledge: the two sources of Religion at the limits of reason alone" (Derrida, 2002a), that Derrida refers to "the island" along with "the Promised Land" and "the desert" as three most impossible places. The resistance to any mapping or passage is intimated here as he describes the impossibility of moving across such terrain. "Three aporetical places: with no way out or an assured path, without itinerary or point of 
arrival, without an exterior with a predictable map and a calculable program" (Derrida, 2002a: 47 emphasis in original).

That islands appear throughout "Faith and knowledge" is unsurprising as Derrida was at the time attending a roundtable discussion (with Gadamer and Vattimo in 1994) on the Isle of Capri in Italy. The event concerned religion's resurrection, ultimately referring to Islam's presence in the modern world, but it commenced with Derrida discussing Christianity alongside his more familiar motifs of truth, life, death, sacrifice and violence. He uses the setting to good effect, enfolded within the ancient world, and refers to other islands including Patmos where John reputedly commenced his writing the Book of Revelations, and Delos which was sacred as the home to deities including Artemis, Dionysus and Ariadne and Apollo's birthplace. But, this figure of the island subtends much more than just a place of religion and history, and Derrida's work likewise has multiple undercurrents.

The island embodies those same difficulties configuring any entity identified in terms of being and belonging as self, community, state and/or territory when it faces absolute otherness at the limits of representation. Therefore, in "Faith and knowledge", after he has problematized the approach to any talk on the sensitive topic of religion (which is so frequently and too simply cast in black and white terms), we see Derrida deciding "to situate such arguments, limit them in time and space" yet he immediately then goes about setting them loose:

Date: 28 February 1994. Place: an island, the isle of Capri. A hotel, a table around which we speak among friends, almost without any order, without agenda, without order of the day, no watchword [mot d'ordre] save for a single word, the clearest and most obscure: religion. We believe we can pretend to believe - fiduciary act - that we share in some pre-understanding... Well - we will have to return to this much laternothing is less pre-assured than such a Faktum... and the entire question of religion comes down, perhaps, to this lack of assurance...

I had at first proposed to bring to the light of day of reflection, misconstruing or denying it as little as possible, an effective and unique situation - that in which we then found ourselves:... a double proposition... raised a double question: of language and of nation... an idiom that is above all inseparable from the social nexus, from the political, familial, ethnic, communitarian nexus, from the nation and from the people: from autochthony, blood and soil, and from the ever more problematic relation to citizenship and to the state...

We are not far from Rome, but are no longer in Rome. Here we are literally isolated for two days, insulated on the heights of Capri, in the difference between the Roman and the Italic... Here, then, is a given whose figure at least, as limit, remains contingent and significant at the same time (Derrida, 2002a: 43-45 emphasis in original).

His contradictory, paradoxical words hint at a deconstructive différance, which has long been at the heart of the Derridean corpus and continues to bleed outwards. Here we find intimations of a community bound by shared belief and understanding with an onto-theological basis as well as grounding in blood and soil. But there is that familiar problem - so explicitly manifest 


\section{S. Williams}

with an island polity - in its double bind of seeming to be quite clearly defined yet resisting any final, authoritative representation.

These matters had earlier been raised by Derrida in relation to the impossibility of aporias when introducing the book of that same name. No exterior or foundational reality (nothing outside the text or its context) can ground such abyssal relations. He therefore emphasises the importance of representation, with language co-implicated in the inevitable contamination and indeterminacy of such phenomena:

...belonging to a language does not compare, at first sight, with inclusion in the space of citizenship, or nationality; natural, historical, or political borders; geography or geopolitics; soil, blood, or social class. As soon as these totalities are over-determined, or rather contaminated, by the events of language ... they, in turn, are no longer thoroughly what they are or what one thinks they are, that is, they are no longer identical to themselves, hence no longer simply identifiable and to that extent no longer determinable (Derrida, 1993: 7 emphasis in original).

The impossibility of the island polity is similar to that of any nation, state or territory claiming sovereignty or what Derrida examines in and as "Declarations of independence" (2002b). This performative speech act brings about the event it names in constituting "we the people" but its iteration necessarily fails in trying so succinctly to represent democracy, for example, which as such must remain open to all, including those members yet to be counted. Any claim to sovereignty is enabled by the enunciation and signature of a proper name that lives on, surviving its subjects and objects, standing in for them in their absence and thus announcing the arrival of their death. In fact, the usual reference back to God then countersigns a freedom and independence which is not theirs alone but rather "sovereignty without sovereignty" (de Ville, 2008).

\section{Only Islands}

It is apposite that the internal contamination and ultimate undermining of any state, community or polity by its own autoimmunity is also present amongst the islands deconstructed by Derrida. Whilst arguing for their impossibility, islands are more than possible. In fact, according to a later paper, it seems for him that there is nothing in our world(s) but islands.

In one of his seminars of 2002-03, lecturing on the Heideggerian concepts of world, infinity and solitude, Derrida made his most profound link to islands when, like Deleuze, he referred to Defoe's Robinson Crusoe. These seminar papers were made available to his friend, literary critic J. Hillis Miller, who has since relayed Derrida's surprising philosophical assertion that each of the species, all men and women, every subjectivity, community and culture (and by implication polity or state) exists without any connection or communion amongst the different worlds of one other. It is a remarkable passage discussed by the critic in two papers (Miller, $2007 \mathrm{a} ; 2007 \mathrm{~b}$ ) and since then by geographers, including myself in the context of island studies (Williams, 2010; also Wylie, 2009). The passage is worth citing at length: 
"Neither animals of different species, nor men of different cultures, nor any individual, animal or human, inhabits the same world as another, however close and similar these living individuals may be (humans or animals), and the difference from one world to the other will remain forever uncrossable, the community of the world being always constructed, simulated by a group of stabilizing positions [dispositifs], more or less stable, therefore also never natural, language in the broad sense, codes of traces being destined, with all the living, to construct a unity of the world always deconstructible and nowhere and never given in nature. Between my world, the "my world"; what I call "my world," and there is no other for me, every other world making up part of it, between my world and every other world, there is initially the space and the time of an infinite difference, of an interruption incommensurable with all the attempts at passage, of bridge, of isthmus, of communication, of translation, of trope, and of transfer which the desire for a world and the sickness of the world [mal du monde], and the being in sickness of the world [l"être en mal de monde] will attempt to pose, to impose, to propose, to stabilize. There is no world, there are only islands." (Derrida, cited in Miller, 2007a: 265-266)

Derrida's emphatic return to islands is perhaps unusual given the more common descriptions of today's world as one of encounters with others, open to difference, and networked in the ebb and flow of international relations and a global political economy. A proliferating connectedness rather than singular isolation is what characterizes the excesses of dissemination as well as much of today's geopolitics. Whilst it is the European Union that Derrida discusses in The Other Heading (1992b: 29), he advocates a polity "that consists precisely in not closing itself off in its own identity and in advancing itself in an exemplary way toward what it is not, toward the other heading or the heading of the other ... the beyond of this modern tradition, another border structure, another shore." Such a polity, like an island, can choose between isolation or connectedness but in either case it establishes identity through the differentiation of otherness.

The propensity for any one community, nation, state or territory to become insular in "closing itself off in its own identity" is especially pronounced on islands. However, we often see them being drawn outwards by the forces of globalization as well as inwards through secessionist or isolationist movements. Furthermore, the tendency for internal friction and rupture is present in most political entities and not just islands. It is identified by Derrida in terms of his conceptualization of "auto-immunity" used to explain how an immune or defence system turns against itself (with terrorist deployments against the U.S., for example, relying on those same communications, transport and military technologies designed, built and used inside that nation). In "Faith and Knowledge", Derrida (2002a: 87) describes it as an "excess above and beyond the living ... what opens the space of death" but most tellingly talks of "...no community that would not cultivate its own auto-immunity, a principle of sacrificial selfdestruction ruining the principle of self-protection (that of maintaining its self-integrity intact), and this in view of some sort of invisible and spectral sur-vival." His notion of auto-immunity embraces the necessity of being open to otherness in our always living-on towards death (Williams and Hay, 2011). 


\section{S. Williams}

Derrida's declaration that there are only islands, in this context, reveals his own well-reasoned refusal to belong but also primarily as the best means for engagement. An Algerian Jew as well as Frenchman, he was insistent in saying "I am not one of the family" and "don't count me in" to signal an independence that he deemed of critical importance. As he explained in dialogue with Maurizio Ferraris:

... I want to keep my freedom, always: this, for me, is the condition not only for being singular and other, but also for entering into relation with the singularity and alterity of others. When someone is one of the family, not only does he lose himself in the herd, but he loses the others as well; the others become simply places, family functions, or places or functions in the organic totality that constitutes a group, school, nation or community of subjects speaking the same language (Derrida \& Ferraris, 2001: 27).

The impossibility of attaining any insularity or closure around the various entities of subjectivity and community implies the necessary inverse in their openness to the other. But an ethical response demands our recognition of them also simply on their own terms. In the context of this paper, it is in terms more precisely of their being in, on or of islands, even if it is perhaps only as islands within islands and amongst many others in a world of islands. Any final decision on the absolute sovereignty of an island will ultimately always be impossible (as it is for all matters of identity and territoriality).

\section{Discussion: Virtually Impossible Endings and Ethical Beginnings}

The idea of an island has been examined here through the lens of poststructuralist philosophy. Firstly, understood as a Deleuzean becoming, it is seen expressed through the geographical relations and constant flux of de- and re-territorialization. Secondly, understood as a Derridean interpretation it is seen in terms of historical narration as both representing and being represented. Aided by these two bodies of poststructuralist thought, we can appreciate how the island as an emergent thing is realized through the words and actions of its political subjects and objects as part of a community or polity. The indivisibility and sovereignty that are thus afforded island peoples and places are momentary and prone to fracture and change despite the proclamations of a unity harking back to a mythical past or anticipating a time still yet to come (often aligned with a precise physical geography as well as the destiny if not history of a shared culture and kinship).

An island's ethical constitution has also been intimated and so warrants further reflection here. Thinking via Deleuze, we can consider an event that materializes change in terms of annexation, occupation, secession, division or dissolution, for example, as a potentially ethical as well as productively political moment. A Deleuzean ethic would thus ask what any one particular manifestation of the island polity might now be capable of (in its becoming-other, with this or that de/re-territorialization).

Deleuze's work - including that written with Guattari and following Spinoza - has encouraged others to pursue similar lines of inquiry, for example, in asking: "What can a body do?" (Buchanan, 1997: 73). Such thinking focuses on the body constituted as an assemblage with powerful capacities arising in its various configurations. It resonates with Derrida's thoughts 
too about the community and autoimmunity as well as an island polity's ethical effects understood as Deleuzean differenciation or political intensity. In this context, an island is much more than just a discreet unit of land made distinct by the water surrounding it. Indeed, islandness is constituted through relationships of difference, including those that arise between a body of land and a body of water, but differentiation is not bound to fixity or limited by containment. Rather, it is the potential for always becoming-other that is immanent to these bodies:

We know nothing about a body until we know what it can do, in other words, what its affects are, how they can or cannot enter into a composition with other affects, with the affects of another body, either to destroy that body or to be destroyed by it, either to exchange actions and passions with it or to join with it in composing a more powerful body (Deleuze \& Guattari, 1987: 257).

Conversely, Derrida might well have us pursue the difficult lines of reason, decision and delimitation hence negation (but then, perhaps, also de-negation). With a Derridean ethical inflection we would thus ponder the island polity as traced in the outlines of its unfolding (irrespective of whether a story of arrival or deferral, anticipating democratic freedom or lapsing into totalitarianism). Still, it too coheres, albeit only ever temporarily, as an entity that resists any one final representation or total disclosure. The island is momentarily insular, distanced and detached in its excessiveness as well as in its inadequacy. As Miller, discussing Derrida as "enisled" and referring to a citation from "Faith and knowledge", states:

Every community, whether it wants to be or not, however much it tries to enclose itself in itself, is open to "the other, the future, death, freedom, the coming or the love of the other, the space and time of a spectralizing messianicity beyond all messianism (Derrida, cited by Miller, 2007a: 271).

Any individual subject, political community or area of practice represented by one essential, enduring form is necessarily problematic - no matter how timely its narration, precise in spatial delimitation, nor seemingly right in its ethical inclusions or extension. The inevitable presence of the other understood as the constitutive outside is attended by promises (usually unspoken) of difference, change and hence demise. In light of writings by Deleuze as well as Derrida, this dynamic is productive as much as negative and driven from within as well as without. Such are the endless possibilities and secrets of islands (Bradshaw \& Williams, 1999; Williams, 2010).

There is one last point to be made in this discussion. Whilst focussing on islands we might also touch on the matter of island studies as a coherently defined field of research. Its remit, according to Baldacchino (2007), extends to such diverse places and multiple forms as human physiology (the islets of Langerhans) and western domestic interiors (island benches in kitchens), and notes how planet Earth is often likened to an island but in itself also comprises a world of islands. Likewise, it seems, island studies is a disciplinary and methodological cornucopia and perhaps impossibly so as almost anything as much as everything goes here (Baldacchino, 2008). It still is constituted as a bounded field of research and practice - if only through being named as such - but its limitations are internal as much as external. 


\section{S. Williams}

Contradictions or what Hay (2006) identifies as fissures can therefore be observed as fracturing island studies and causing possible weakness (unless opened up and explored in productive ways).

An array of self-proclaimed island scholars and others (myself included) have variously spoken and written island studies into existence. However, as the critical mass now formed through these efforts revolves around an international hub of leading academics and key publications, some of us might be well advised to look back again to the margins or periphery. The difference and otherness of islands in all their number and variety are what has always grounded island studies. There is a paradox therefore in their unification so as to create the one distinctly coherent body of work that is island studies. However, it seems here (from reading Derrida and Deleuze) that the subjects and objects of this discreet field may never constitute any properly definitive entity. Instead, it will likely continue in various ways to suffer internal complications but also escape the frame of reference and combine with what lies outside and beyond. These inherent failings and irruptive excesses precede island studies' own dissolution but could also deliver its ongoing reinvention.

Of course, good island studies scholarship has already commenced such reflexive, internal critique. Hence several leading island scholars have continued to engage in robust debate as well as to call attention to the sophisticated nuances and complexity that holds here (see, for example, Baldacchino, 2005, 2006, 2007, 2008; Hay, 2006; Stratford, 2003; Stratford et al., 2011). They are not in agreement though: Hay (2006), for example, urges a return to dealing with 'real' not metaphoric islands. Still, these scholars have identified the need for more adequate theorization of our field with its extensive and alluring but also elusive content. Literary scholars have similarly commented on our existence in a hybridized world where 'every island (ethnicity, nation and the like) is but a fragment of the whole that is always already in the process of transforming the particular into something other than its (original, essential) self' (Bongie, 1998: 18). Likewise, Fletcher reiterates others' views on island studies still having 'some distance to go' as she sees need for a more sophisticated conceptual framework which might be found in performative geography:

The benefits of this approach are potentially manifold: it begins with an acknowledgement of the mutually constructive relationship of description of islands (in multiple media) and their material and social reality; it provides a fresh conceptual model for considering islands as productive of individual and social identity; and, perhaps most importantly, it insists that islands are always already places in process (Fletcher, 2011: 30).

This paper's offering a Deleuzo-Derridean conceptualization of islands and island studies provides another such theorization but one with an explicitly political poststructuralist bent. Amidst these musings then, and from a more practical perspective, one might therefore wonder whether or not island studies has really started to embrace its full potential. Instead, it is yet to be cut loose from the stays of our still very traditional, academic moorings (anchored to structures derived over the millennia from our western philosophical paradigm). Consider, for example, Baldacchino's (2006, 2007) emphasis on scholarly publication, postgraduate courses, 
and citation metrics and ranking processes which afford a recognition that is perhaps really valued only at or near the centre.

In noting such contradictions, this paper invites further reflection on the virtual impossibility of island studies as well as that of islands per se. Key here is the ethical inflection which has us ask what is it that island studies has internalised with its delimitation as such? And to what effect, or with what exclusions? We might therefore inquire into its constitutive outside and the prospect for engaging in different relationships or the need perhaps as well as the possibilities for islands and island studies to be otherwise. What will happen as island studies scholarship resists the metropolitan academy with all its particular, professorial practices? What about if or when the ideas, activities and interests of everyday island peoples are truly engaged with and more supportively launched (and are perhaps driving island studies)? These sorts of questions might challenge many scholars and seem destructive as they pose some end or finality here. However, they are precisely what might also permit a more empowering and productive, specifically archipelagic efflorescence rather than island studies. It has, for example, been through addressing the limitations of insularity (interpreted as isolation, backwardness, constraint and decline) that island scholarship has already pushed and crossed many boundaries as it makes and re-makes itself anew.

\section{Conclusion}

Together with Deleuze and Derrida, we have encountered the island in relating differences that are internal and external, immanent and transcendent. An island is constituted through its proclamations and performances as a political entity that is mythological and scientific, real and imaginary; so, whilst often founded on some theological as well as empirical basis, it also gets situated in a particular space and time. The repetition and reiteration of such representations and enactments create a multiplicity of worlds that are explored here, and best understood, in terms of the virtual and the impossible. Indeed, islands and our studies of them are brought into being through processes of becoming (rather than just being) which then also render them virtually impossible.

The virtually impossible is a concept assembled here from Derridean deconstruction and Deleuzean affirmation. It draws together two lines of poststructuralist thought which have most often been left counterpoised. With additional space we could consider ways to integrate more fully the work of these two authors. Still, it suffices here to note how they are productive foils for each other as their writings on islands reinforce the use of each other's work in the context of island studies and resonate with the most significant ideas drawn from their philosophical legacies. As a result, island scholars will hopefully be inspired and rewarded by further exploring the oeuvres of Deleuze and Derrida in efforts to progress our field's development. Here, the island is already deemed an awkwardly complex entity, but viewed through their poststructural theory it is problematized in the political terms of an indivisible sovereignty. Deleuzean virtuality and Derridean impossibility used together provide ways to move forward but with all the ambivalences and contradictions (and possibilities) of islandness kept in play. Hence there is no need to favour either the ideal over the material or openness over closure when engaging with the problematic of the island polity because a Deleuzo-Derridean interpretation permits both negation and affirmation, though never simply dialectical nor 


\section{S. Williams}

additive. The virtually impossible entails all the possibilities of actualization in this or any other world. It therefore marshals inevitabilities to come (even though they may not yet have been anticipated) as well as undecidable junctures and moments of occlusion that comprise seemingly impassable points in time and space (including those long since past).

Islands embody the virtually impossible. They have long been associated with representations of fixity and bounded containment that are often purposefully retained but also now challenged and shifted, for example, in the field of island studies. Claims to stasis or insularity still find parallels in the political calls for absolute sovereignty as well as the attendant faith in those territorial delimitations which seem to be making a comeback in the face of our current era's characteristic globalising forces of deracination, placelessness and flow. It seems clear from this study, however, that in marking out these identifications in terms of a self-sameness or one-ness, such an entity is necessarily also then articulated with its other (understood as the wholly Other). Subsequently, whilst these entities - in this case, islands and island phenomena - are being realized as identical with themselves, they are at the same time actually made available for becoming otherwise. They can and possibly must therefore continue to look outwards whilst still also reflecting inwardly. Such a stance has become the norm with much island studies scholarship but it deserves re-statement here not least because it flags inevitable and ineffable changes (which often remain unacknowledged or discussed) and intimates how they might best be faced.

In our poststructuralist critique, this recursive movement arises from a combined reading of Deleuze and Derrida. One's pessimism and the other's optimism sit well together with the many ambiguities and contradictions of islands but also lead into an intriguing political doubleplay around island studies. Islands and island phenomena, and likewise our studies of them, are constituted inside and out by many peoples and places, each absolutely singular and individual. Whilst resisting our representations of them, their engagement is critical, and it is with such island peoples and places that we remain responsible for extending ethical relations without end. This realization is terminal though, as it smacks of death as well as life. The death knell is sounded for the more traditional ideas that abound about islands and perhaps likewise for our thinking of them as encompassed by island studies in its currently familiar form. Yet, if we do encounter the demise of island studies in its current form, we need not fear, resist or simply mourn its passing. Celebration is warranted too, as new beginnings as well as endings inhere in an always immanent becoming-other. Thus might we cry: Island Studies is dead. Long live the study of islands!

\section{Acknowledgements}

This paper has benefited from my interactions over several years with respected island studies scholars Elaine Stratford, Andrew Harwood, Peter Hay, Phil Hayward and Eric Clark, amongst others, as well as the comments most recently of Island Studies Journal's anonymous reviewers. The usual disclaimers apply. 


\section{References}

Baldacchino, G. (2005) 'Islands: Objects of Representation', Geografiska Annaler B, Vol. 87, No. 4, pp. 247-251.

Baldacchino G. (2006) 'Islands, Island Studies, Island Studies Journal', Island Studies Journal, Vol. 1, No. 1, pp. 3-18.

Baldacchino G. (ed.) (2007) A World of Islands: An Island Studies Reader, Charlottetown, Institute of Island Studies, University of Prince Edward Island.

Baldacchino, G. (2008) 'Studying Islands: On Whose Terms?', Island Studies Journal, Vol. 3, No. 1, pp. 37-56.

Beardsworth, R. (1996) Derrida and the Political, New York, Routledge.

Bearn, G.C.F. (2000) 'Differentiating Derrida and Deleuze', Continental Philosophy Review, Vol. 33, No. 4, pp. 441-465.

Bongie, C. (1998) Islands and Exiles: The Creole Identities of Post/Colonial Literature, Stanford CA, Stanford University Press.

Bonta, M. \& Protevi, J. (2004) Deleuze and Geophilosophy: A Guide and Glossary, Edinburgh, Edinburgh University Press.

Boundas, C.V. (1994) 'Deleuze: Serialization and Subject-formation' in C.V. Boundas \& D. Olkowski (eds.) Gilles Deleuze and the Theater of Philosophy, New York, Routledge, pp. 99116.

Bradshaw, M. \& Williams, S. (1999) 'Scales, Lines and Minor Geographies: Whither King Island?', Australian Geographical Studies, Vol. 37, No. 3, pp. 248-267.

Buchanan, I. (1997) 'The Problem of the Body in Deleuze and Guattari, or, What can a Body do?,' Body \& Society, Vol. 3, No. 1, pp. 73-91.

Buchanan, I. \& Lambert, G. (eds.) (2005) Deleuze and Space, Edinburgh, Edinburgh University Press.

Conley, T. (2005) 'The Desert Island' in I. Buchanan \& G. Lambert (eds.) Deleuze and Space, Edinburgh, Edinburgh University Press, pp. 207-219.

Defoe, D. (1900 [1719]) Robinson Crusoe, London, Collins.

Deleuze, G. (1988) Bergsonism, translated by H. Tomlinson \& B. Habberjam, New York, Zone Books. 


\section{S. Williams}

Deleuze, G. (1990) 'Michel Tournier and the World without Others' in C.V. Boundas (ed.) The Logic of Sense, translated by M. Lester with C. Stivale, New York, Columbia University Press, pp. 301-321.

Deleuze, G. (1994) Difference and Repetition, translated by P. Patton, London, Athlone Press.

Deleuze, G. (2004) 'Desert Islands' in G. Deleuze Desert Islands and Other Texts: 1953-1974, translated by M. Taormina, Paris, Semiotext(e), pp. 9-14.

Deleuze, G. \& Guattari, F. (1987) A Thousand Plateaus: Capitalism and Schizophrenia, translated by B. Massumi, Minneapolis MN, University of Minnesota Press.

Deleuze, G. and Guattari, F. (1994) What is Philosophy?, translated by H. Tomlinson \& G. Burchell, London, Verso.

Derrida, J. (1982) Margins of Philosophy, translated by A. Bass, Brighton, Harvester Press.

Derrida, J. (1990) 'Force of Law: The Mystical Foundations of Authority', Cardozo Law Review, Vol. 11, Nos.5-6, pp. 920-1045.

Derrida, J. (1992a) 'Before the Law' in D. Attridge (ed.) Acts of Literature translated by A. Ronell \& C. Roulston, New York, Routledge, pp. 181-220.

Derrida, J. (1992b) The Other Heading: Reflections on Today's Europe, translated by P.-A. Brault \& M.B. Naas, Bloomington IN, Indiana University Press.

Derrida, J. (1993) Aporias: Dying-awaiting (one another) at the "Limits of Truth", translated by T. Dutoit, Stanford CA, Stanford University Press.

Derrida, J. (1995) 'Passions' in T. Dutoit (ed.) On the Name, translated by D. Wood, J.P. Leavey \& I. McLeod, Stanford CA, Stanford University Press, pp.1-31.

Derrida, J. (1999) 'Hospitality, Justice and Responsibility: A Dialogue with Jacques Derrida' in R. Kearney \& M. Dooley (eds.) Questioning Ethics: Contemporary Debates in Philosophy, New York, Routledge, pp. 65-83.

Derrida, J. (2002a) 'Faith and Knowledge: The Two Sources of Religion at the Limits of Reason alone', in G Anidjar (ed.) Acts of Religion, translated by S. Weber, New York, Routledge, pp. 42-101.

Derrida, J. (2002b) 'Declarations of Independence' in Negotiations: Interventions and Interviews: 1971-2001, Stanford CA, Stanford University Press, pp. 46-54.

Derrida, J. \& Ferraris, M. (2001) A Taste for the Secret, translated by G. Donis, Cambridge, Polity Press. 
Doel, M. (2000) 'Un-glunking Geography: Spatial Science after Dr Seuss and Gilles Deleuze' in M. Crang \& N. Thrift (eds.) Thinking Space, London, Routledge, pp. 117-135.

Fletcher, L. (2011) ““... some distance to go”: A Critical Survey of Island Studies', New Literatures Review, Vol. 47/48, pp. 17-34.

Giraudoux, J. (1975 [1921]) Suzanne and the Pacific, New York, Howard Fertig.

Hay, P. (2006) ‘A Phenomenology of Islands', Island Studies Journal, Vol. 1, No. 1, pp. 1942.

Lambert, G. (2005) 'What the Earth thinks' in I. Buchanan \& G. Lambert (eds.) Deleuze and Space, Edinburgh, Edinburgh University Press, pp. 220-239.

Miller, J.H. (2007a) 'Derrida enisled', Critical Inquiry, Vol. 33, No. 2, pp. 248-276.

Miller, J.H. (2007b) 'Don't count me in: Derrida's Refraining', Textual Practice, Vol. 21, No. 2, pp. 279-294.

Patton, P. (2000) Deleuze and the Political, London \& New York, Routledge.

Patton, P. \& Protevi, J. (eds.) (2003) Between Deleuze and Derrida, New York, Continuum.

Royle, S.A. (2001) A Geography of Islands: Small Island Insularity, London, Routledge.

Smith, D.W. (2003) 'Deleuze and Derrida, Immanence and Transcendence' in P. Patton \& J. Protevi (eds.) Between Deleuze and Derrida, London, Continuum, pp. 46-66.

Steinberg, P. (2005) 'Insularity, Sovereignty and Statehood: The Representation of Islands on Portolan Charts and the Construction of the Territorial State', Geografiska Annaler B, Vol. 87, No. 4, pp. 253-64.

Steinberg, P. (2009) 'Sovereignty, Territory, and the Mapping of Mobility: A View from the Outside', Annals of the Association of American Geographers, Vol. 99, No. 3, pp.467-495.

Stratford, E. (2003) 'Editorial: Flows and Boundaries: Small Island Discourses and Challenges of Sustainability, Community \& Local Environments', Local Environment, Vol. 8, No. 5, pp. 495-499.

Stratford, E., Baldacchino, G., McMahon, E., Farbotko, C. \& Harwood, A. (2011) 'Envisioning the Archipelago', Island Studies Journal, Vol. 6, No. 2, pp. 113-130

de Ville, J. (2008) 'Sovereignty without Sovereignty: Derrida's Declarations of Independence', Law \& Critique, Vol. 19, No. 2, pp. 87-114. 


\section{S. Williams}

Williams, S. (2010) 'On Islands, Insularity and Opium Poppies: Australia's Secret Pharmacy', Environment \& Planning D: Society and Space, Vol. 28, No. 2, pp. 290-310.

Williams, S. \& Hay, P. (2011) 'Living on... A Conversation about Island Peoples, Places, Politics and Poetry', Island, Vol. 124, pp. 8-16.

Wylie, J. (2009) 'Landscape, Absence and the Geographies of Love', Transactions of the Institute of British Geographers, Vol. 34, No. 3, pp. 275-289. 